University of Nebraska - Lincoln

DigitalCommons@University of Nebraska - Lincoln

\title{
Climate Impacts on Agriculture: Implications for Forage and Rangeland Production
}

R. C. Izaurralde

University of Maryland - College Park, cizaurra@umd.edu

A. M. Thomson

University of Maryland - College Park

J. A. Morgan

USDA-ARS

P. A. Fay

USDA-ARS, philip.fay@ars.usda.gov

H. W. Polley

USDA-ARS, wayne.polley@ars.usda.gov

See next page for additional authors

Follow this and additional works at: https://digitalcommons.unl.edu/usdaarsfacpub

Izaurralde, R. C.; Thomson, A. M.; Morgan, J. A.; Fay, P. A.; Polley, H. W.; and Hatfield, J. L., "Climate Impacts on Agriculture: Implications for Forage and Rangeland Production" (2011). Publications from USDA-ARS / UNL Faculty. 1351.

https://digitalcommons.unl.edu/usdaarsfacpub/1351

This Article is brought to you for free and open access by the U.S. Department of Agriculture: Agricultural Research Service, Lincoln, Nebraska at DigitalCommons@University of Nebraska - Lincoln. It has been accepted for inclusion in Publications from USDA-ARS / UNL Faculty by an authorized administrator of DigitalCommons@University of Nebraska - Lincoln. 


\section{Authors}

R. C. Izaurralde, A. M. Thomson, J. A. Morgan, P. A. Fay, H. W. Polley, and J. L. Hatfield 


\title{
Climate Impacts on Agriculture: Implications for Forage and Rangeland Production
}

\author{
R. C. Izaurralde, A. M. Thomson, J. A. Morgan, P. A. Fay, H. \\ W. Polley, and J. L. Hatfield*
}

\begin{abstract}
Projections of temperature and precipitation patterns across the United States during the next $50 \mathrm{yr}$ anticipate a 1.5 to $2^{\circ} \mathrm{C}$ warming and a slight increase in precipitation as a result of global climate change. There have been relatively few studies of climate change effects on pasture and rangeland (grazingland) species compared to those on crop species, despite the economic and ecological importance of the former. Here we review the literature on responses of pastureland and rangeland species to rising atmospheric $\mathrm{CO}_{2}$ and climate change (temperature and precipitation) and discuss plant and management factors likely to influence pastureland and rangeland responses to change (e.g., community composition, plant competition, perennial growth habit, seasonal productivity, and management methods). Overall, the response of pastureland and rangeland species to increased $\left[\mathrm{CO}_{2}\right]$ is consistent with the general responses of $\mathrm{C}_{3}$ and $\mathrm{C}_{4}$ vegetation, although exceptions exist. Both pastureland and rangeland species may experience accelerated metabolism and advanced development with rising temperature, often resulting in a longer growing season. However, soil resources will often constrain temperature effects. In general, it is expected that increases in $\left[\mathrm{CO}_{2}\right]$ and precipitation will enhance rangeland net primary production (NPP) whereas increased air temperatures will either increase or decrease NPP. Much of the uncertainty in predicting how pastureland and rangeland species will respond to climate change is due to uncertainty in future projections of precipitation, both globally and regionally. This review reveals the need for comprehensive studies of climate change impacts on pastureland and rangeland ecosystems that include an assessment of the mediating effects of grazing regimes and mutualistic relationships (e.g., plant roots-nematodes; $\mathrm{N}$-fixing organisms) as well as changes in water, carbon, and nutrient cycling.
\end{abstract}

$I^{N}$ NCREASING ATMOSPHERIC CONCENTRATIONS of $\mathrm{CO}_{2}\left(\left[\mathrm{CO}_{2}\right]\right)$ and other greenhouse gases are increasing air temperatures and altering precipitation patterns globally, including in the Northern Hemisphere, with consequent impacts on agricultural systems (Hatfield et al., 2008, 2011). Pastureland and rangeland ecosystems, so important worldwide for the goods and services they produce and the cultures they support, are certain to be significantly affected by climate change and rising $\left[\mathrm{CO}_{2}\right]$ (Morgan, 2005). There is general agreement that over the next 30 to $50 \mathrm{yr},\left[\mathrm{CO}_{2}\right]$ will increase beyond $450 \mu \mathrm{mol} \mathrm{mol}^{-1}\left(1 \mathrm{ppm} \mathrm{CO}_{2}=1 \mu \mathrm{L} \mathrm{CO}_{2} \mathrm{~L}^{-1}\right.$ air), global mean temperature will increase by at least 0.8 to $1.0^{\circ} \mathrm{C}$, and precipitation will become more variable (IPCC, 2007). Changes in temperature have already led to longer growing seasons and directly impacted phenological phases (Schwartz et al., 2006). These observed and expected climatic trends illus-

R.C. Izaurralde and A.M. Thomson, Joint Global Change Research Institute (Pacific Northwest National Lab. and Univ. of Maryland), 5825 Univ. Research Ct., Suite 3500, College Park, MD 20740; J.A. Morgan, USDAARS, Crops Research Lab., 1701 Center Ave., Fort Collins, CO 80526; P.A. Fay and H.W. Polley, USDA-ARS, Grassland Soil and Water Research Lab., 808 E. Blackland Rd., Temple, TX 76502; J.L. Hatfield, USDA-ARS, National Lab. for Agriculture and the Environment, 2110 University Blvd., Ames, IA 50011-3120. Received 9 July 2010. *Corresponding author (jerry. hatfield@ars.usda.gov).

Published in Agron. J. 103:371-381 (2011)

Published online 30 Dec 2010

doi:10.2134/agronj2010.0304

Copyright (c) 2011 by the American Society of Agronomy, 5585 Guilford Road, Madison, WI 53711. All rights reserved. No part of this periodical may be reproduced or transmitted in any form or by any means, electronic or mechanical, including photocopying, recording, or any information storage and retrieval system, without permission in writing from the publisher. trate the need for continued research on the potential impacts of climate change and $\left[\mathrm{CO}_{2}\right]$ on agricultural production.

In the United States, the geographic distribution of pasturelands and rangelands follows the distribution of precipitation, with the ecotone between the two regions roughly running North-South along longitude $97^{\circ} \mathrm{W}$ (Fig. 1). The complex character of pasturelands and rangelands, comprised of multiple interacting perennial and annual plants as well as animal species, challenges our understanding of how these agro-ecosystems will respond to climate change. The impacts of climate change on agricultural production were reviewed as part of the Climate Change Science Program (CCSP) (Hatfield et al., 2008). The objective of this review is to expand on some of those findings and offer recommendations for future research and technology development aimed at optimizing the performance of pastureland and rangeland production systems in a changing climate regime.

\section{BASIC PLANT RESPONSES TO ELEVATED [CARBON DIOXIDE], TEMPERATURE, AND PRECIPITATION}

Meta-analyses of numerous greenhouse, growth chamber, and field studies confirm a general positive response of plants to elevated $\left[\mathrm{CO}_{2}\right]$ in terms of leaf photosynthesis, biomass, and yield (Kimball 1983; Amthor, 2001; Jablonski et al., 2002; Kimball et al., 2002; Ainsworth and Long, 2005; Tubiello et al., 2007; Hatfield et al., 2011). On average, a doubling of $\left[\mathrm{CO}_{2}\right]$ increases reproductive yield by $30 \%$ in $\mathrm{C}_{3}$ species and by $10 \%$ in $\mathrm{C}_{4}$ species (Hatfield et al., 2011). Many environmental factors, including temperature, precipitation, ozone, and nutrient availability interact

Abbreviations: NPP, net primary production; SOM, soil organic matter. 


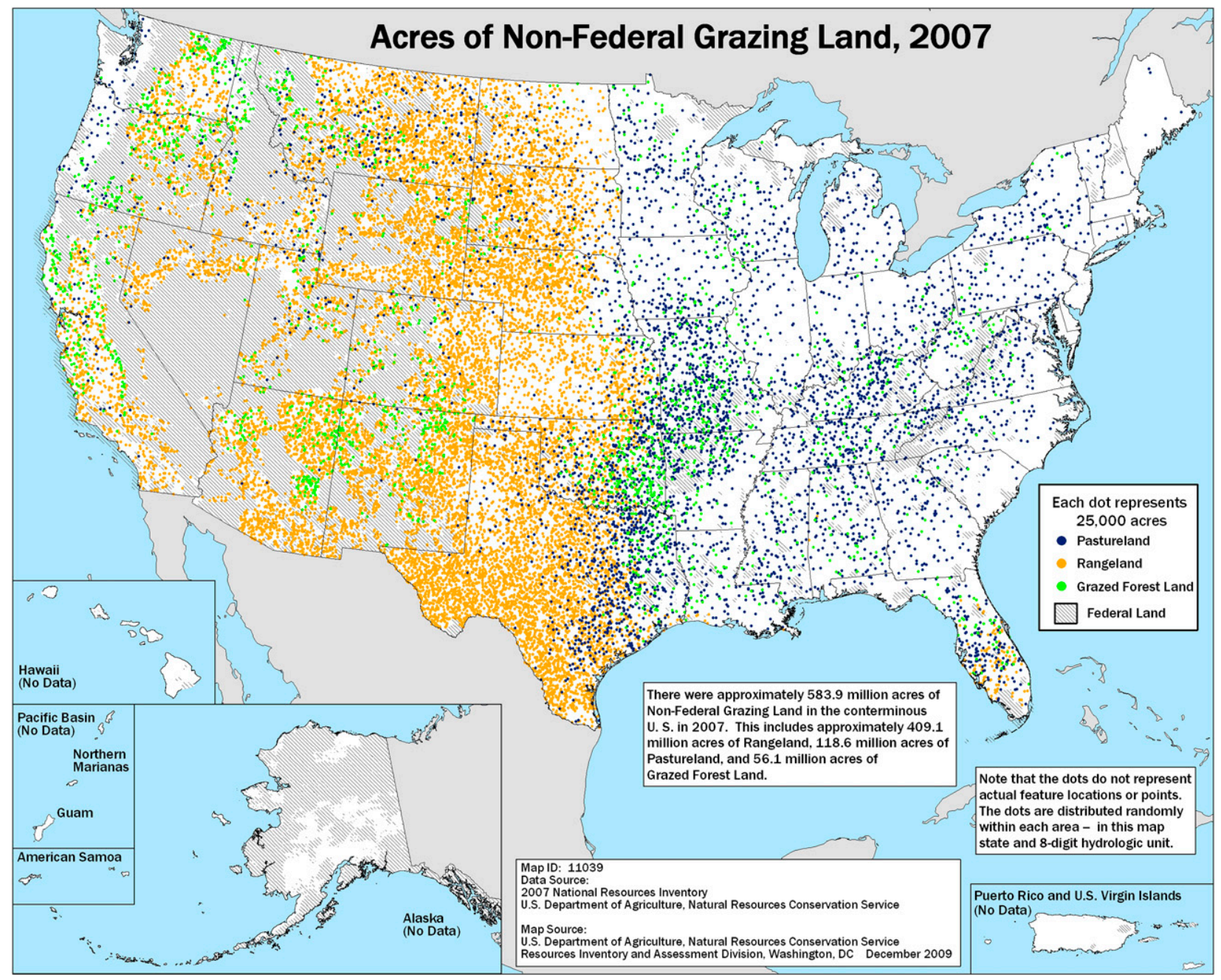

Fig. I. Distribution of pastureland across the United States in 1997 (www.nrcs.usda.gov/technical) $(\mathrm{I}$ acre $=0.4047 \mathrm{ha})$.

with $\left[\mathrm{CO}_{2}\right]$ thereby leading to lower than expected plant response under some environmental combinations (e.g., increased temperature and decreased soil moisture) (Amthor, 2001; Tubiello et al., 2007; Long et al., 2006). By contrast, rising temperatures may have either positive or negative effects on plant productivity, depending on the current climate regime and the availability of soil resources (Hatfield et al., 2011). Increasing precipitation in some regions may enhance plant production, although increased variability in rainfall in concert with warmer, desiccating temperatures may lead to regional drought (Wang, 2005). The following sections give some glimpses into basic mechanisms of plant and ecosystem-level responses to $\left[\mathrm{CO}_{2}\right]$ and climate change.

\section{Pastureland Responses}

\section{Elevated [Carbon Dioxide],}

\section{Temperature, and Soil Moisture}

In a growth chamber study, Greer et al. (1995) examined the photosynthetic response of 13 different pasture species to elevated $\left[\mathrm{CO}_{2}\right]\left(350\right.$ and $\left.700 \mu \mathrm{mol} \mathrm{mol}^{-1}\right)$ and daytime/nighttime temperatures of $12 / 7,18 / 13$, and $28 / 23^{\circ} \mathrm{C}$. With elevated $\left[\mathrm{CO}_{2}\right]$, leaf photosynthetic rates increased by $40 \%$ in $\mathrm{C}_{3}$ species, but were largely unaffected in $\mathrm{C}_{4}$ species. Response of $\mathrm{C}_{3}$ species to elevated $\left[\mathrm{CO}_{2}\right]$ decreased as temperatures increased from 12 to $28^{\circ} \mathrm{C}$; however, the temperatures at which the maximum rates of photosynthesis occurred varied with species and $\left[\mathrm{CO}_{2}\right]$. At $350 \mu \mathrm{mol} \mathrm{mol}^{-1}$, four species (Lolium multiflorum, Agrostis capillaris, Cichorium intybus, and Paspalum dilatatum Poir.) exhibited maximum rates of photosynthesis at $18^{\circ} \mathrm{C}$ whereas remaining species (Bromus wildenowii, Lolium perenne, Phalaris aquatica, Trifolium subterraneum, Dactylis glomerata, Festuca arundinacea, Trifolium repens, and Digitaria sanguinalis), exhibited a maximum rate at $28^{\circ} \mathrm{C}$. At $700 \mu \mathrm{mol}$ $\mathrm{mol}^{-1}$, photosynthetic rates shifted upward from 18 to $28^{\circ} \mathrm{C}$ in $A$. capillaries and downward from 28 to $18^{\circ} \mathrm{C}$ in $L$. perenne, F. arundinacea, B. wildenowii, and T. subterraneum. However, no correlation was found between the temperature response of photosynthesis and the climatic adaptations of these pasture species.

The same $\mathrm{C}_{3}-, \mathrm{C}_{4}$-type of response was observed in another study conducted in temperature-gradient greenhouses that included a $\mathrm{C}_{3}$ forage legume rhizoma peanut (Arachis hagenbeckii Harms) (Newman et al., 2001) and a $\mathrm{C}_{4}$ grass bahiagrass (Paspalum notatum Flueggé), both introduced forage species common in the U.S. Southeast. Both species were grown under current $\left(360 \mu \mathrm{mol} \mathrm{mol}^{-1}\right)$ and elevated $\left(700 \mu \mathrm{mol} \mathrm{mol}^{-1}\right)$ $\left[\mathrm{CO}_{2}\right]$ and with baseline temperature and three levels of temperature increase $\left(\mathrm{B}+1.5, \mathrm{~B}+3.0\right.$, and $\left.\mathrm{B}+4.5^{\circ} \mathrm{C}\right)$. Under optimal water and nutrient conditions, only rhizoma peanut exhibited yield increase at elevated $\left[\mathrm{CO}_{2}\right](+25 \%)$. Both species exhibited positive yield responses to elevated temperatures.

The Swiss free air carbon dioxide enrichment (FACE) experiment evaluated the impacts of ambient $\left(360 \mu \mathrm{mol} \mathrm{mol}^{-1}\right)$ and 
Table I. Simulated changes in alfalfa yields with respect to baseline climate in major US regions and changes in annual temperature and precipitation under three climate change projections around 2030 (from Izaurralde et al. (2003) and Thomson et al., 2005).

\begin{tabular}{|c|c|c|c|c|c|c|c|c|c|c|}
\hline \multirow[b]{3}{*}{ Region $\dagger$} & \multirow[b]{3}{*}{$\mathrm{CO}_{2}$} & \multicolumn{3}{|c|}{$\operatorname{HadCM} 2 \ddagger$} & \multicolumn{3}{|c|}{ BMRC§ } & \multicolumn{3}{|c|}{ UIUCף } \\
\hline & & $\Delta \mathrm{T}$ & $\Delta \mathbf{P}$ & Yield & $\Delta \mathbf{T}$ & $\Delta \mathbf{P}$ & Yield & $\Delta \mathbf{T}$ & $\Delta \mathbf{P}$ & Yield \\
\hline & & ${ }^{\circ} \mathbf{C}$ & $\mathrm{mm}$ & $\%$ change & ${ }^{\circ} \mathbf{C}$ & $\mathbf{m m}$ & $\%$ change & ${ }^{\circ} \mathbf{C}$ & $\mathbf{m m}$ & $\%$ change \\
\hline \multirow[t]{2}{*}{ Great Lakes } & 365 & 1.13 & 74 & 17.0 & 1.79 & -6 & -0.4 & 0.96 & 19 & -1.3 \\
\hline & 560 & & & 20.6 & & & 0.0 & & & -1.0 \\
\hline \multirow[t]{2}{*}{ Ohio } & 365 & 0.70 & 80 & 12.5 & 1.66 & -16 & -5.2 & 0.86 & 25 & -3.7 \\
\hline & 560 & & & 13.9 & & & -5.0 & & & -3.8 \\
\hline \multirow[t]{2}{*}{ Upper Mississippi } & 365 & 1.24 & 74 & 10.9 & 1.71 & -14 & -3.4 & 0.89 & 29 & -2.2 \\
\hline & 560 & & & 14.8 & & & -2.5 & & & -2.1 \\
\hline \multirow[t]{2}{*}{ Souris-Red-Rainy } & 365 & 1.40 & -30 & -30.7 & 1.73 & -3 & -1.9 & 0.96 & 12 & -0.4 \\
\hline & 560 & & & -25.4 & & & 2.1 & & & 2.6 \\
\hline \multirow[t]{2}{*}{ Missouri } & 365 & 1.42 & 34 & -9.2 & 1.50 & -18 & -9.4 & 0.92 & 41 & 3.5 \\
\hline & 560 & & & -7.1 & & & -9.1 & & & 3.1 \\
\hline \multirow[t]{2}{*}{ Arkansas } & 365 & 1.77 & -2 & -18.6 & 1.53 & -32 & -9.6 & 0.76 & 61 & 3.8 \\
\hline & 560 & & & -14.2 & & & -7.3 & & & 5.1 \\
\hline \multirow[t]{2}{*}{ Rio Grande } & 365 & 3.11 & 12 & 5.0 & $\mathrm{I} .4 \mathrm{I}$ & -20 & -9.3 & 0.84 & 25 & 16.2 \\
\hline & 560 & & & 5.3 & & & -8.7 & & & 17.8 \\
\hline \multirow[t]{2}{*}{ Upper Colorado } & 365 & 2.21 & 76 & 5.0 & 1.48 & -18 & -15.3 & 0.97 & 40 & 16.2 \\
\hline & 560 & & & 5.4 & & & $-|4|$. & & & 16.7 \\
\hline \multirow[t]{2}{*}{ Lower Colorado } & 365 & 1.43 & 2 & 7.3 & 1.31 & -23 & -16.0 & 0.97 & 27 & 7.8 \\
\hline & 560 & & & 11.9 & & & -19.4 & & & 4.7 \\
\hline \multirow[t]{2}{*}{ Great Basin } & 365 & 0.62 & 21 & -4.7 & 1.36 & -15 & -6.3 & 1.07 & 45 & 24.2 \\
\hline & 560 & & & -4.5 & & & -7.1 & & & 23.7 \\
\hline \multirow[t]{2}{*}{ Pacific Northwest } & 365 & 0.45 & 3 & 0.4 & 1.24 & -6 & 2.0 & 1.11 & 54 & 8.4 \\
\hline & 560 & & & 1.7 & & & 1.9 & & & 8.1 \\
\hline \multirow[t]{2}{*}{ California } & 365 & 0.95 & 58 & 8.7 & 1.13 & -45 & -5.5 & 1.08 & 17 & 6.3 \\
\hline & 560 & & & 9.3 & & & -3.5 & & & 4.6 \\
\hline
\end{tabular}

† The regions follow approximately large basin delineations and are ordered from East to West and from North to South in the conterminous United States.

$\ddagger$ Hadley Center Climate Model 2.

$\S$ Australian Bureau of Meteorology Research Center.

TI University of Illinois Urbana-Champagne.

elevated $\left(600 \mu \mathrm{mol} \mathrm{mol}^{-1}\right)\left[\mathrm{CO}_{2}\right]$ on regrowth characteristics of perennial ryegrass (L. perenne L.) (Suter et al., 2001). They found that elevated $\left[\mathrm{CO}_{2}\right]$ increased root mass by $68 \%$, pseudostems by $38 \%$, and shoot necromass below cutting height by $45 \%$ during the entire regrowth period. Yield, total dry matter, and leaf area index strongly increased with elevated $\left[\mathrm{CO}_{2}\right]$ during the first part of the regrowth cycle but not during the second, suggesting that a lack of a strong sink for the extra $\mathrm{C}$ fixed during the latter period eliminated the $\mathrm{CO}_{2}$ response (Suter et al., 2001).

Although average global precipitation is expected to increase, warmer temperatures will sometimes nullify or reverse positive effects of increased precipitation on plant production through heat stress and desiccation (IPCC, 2007; Wang, 2005). Furthermore, increased precipitation and warmer temperature may partially negate positive effects of rising $\left[\mathrm{CO}_{2}\right]$ on plant water use efficiency (Morgan et al., 2004b). Thus, the interactions of all three global change factors can have complex effects on plant production, in no small part through their combined effects on water relations.

The interactions of elevated $\left[\mathrm{CO}_{2}\right]$ and soil water limitations on temperate pasture growth have been studied in New Zealand (Newton et al., 1996, 2006). Intact turves composed primarily of perennial ryegrass and dallisgrass ( $P$. dilatatum Poir.) were grown in growth rooms for $324 \mathrm{~d}$ under two concentrations of $\mathrm{CO}_{2}\left(350\right.$ and $\left.700 \mu \mathrm{mol} \mathrm{mol}^{-1}\right)$ with air temperatures and photoperiod designed to emulate the monthly climate of the region (Newton et al., 1996). After equilibration, half the turves in each $\left[\mathrm{CO}_{2}\right]$ treatment underwent soil water deficit for $42 \mathrm{~d}$. Turves grown under elevated $\left[\mathrm{CO}_{2}\right]$ continued to exchange $\mathrm{CO}_{2}$ with the atmosphere while turves under ambient $\left[\mathrm{CO}_{2}\right]$ ceased to exchange $\mathrm{CO}_{2}$. A subsequent $\mathrm{FACE}$ experiment in a New Zealand pasture revealed that grazing could affect $\mathrm{CO}_{2}$-water deficit interactions (Newton et al., 2006). Exposing pastures to $\mathrm{CO}_{2}$-enriched atmospheres $\left(475 \mu \mathrm{mol} \mathrm{mol}^{-1}\right)$ enhanced soil water content, but only in those grazed by sheep (Ovis aries). Carbon dioxide fixation was greater in the $\mathrm{CO}_{2}$-enriched pastures, especially during periods of water deficit, with additional $\mathrm{C}$ being allocated primarily to belowground structures, increasing root exudation and enhancing root turnover.

Alfalfa (Medicago sativa $\mathrm{L}$.), an important forage crop for animal production, has been the subject of large scale simulation model studies that evaluated climate impacts on yield. Alfalfa production in the United States has been simulated using the EPIC agroecosystem model (Williams et al., 1989), and various climate change projections from Global Climate Models (GCMs); HadCM2 (Izaurralde et al., 2003), Australia’s Bureau of Meteorology Research Centre (BMRC) and University of Illinois, Urbana-Champaign (UIUC) (Thomson et al., 2005). All model runs were conducted under $\mathrm{CO}_{2}$ concentrations of 365 and $560 \mu \mathrm{mol} \mathrm{mol}^{-1}$ assuming non-irrigated conditions. The results provided an assessment of pastureland response to temperature, precipitation, and $\left[\mathrm{CO}_{2}\right]$ changes in major regions of the United States (Table 1). Variation in precipitation was 
found to have the greatest impact on alfalfa yield at regional scales. Under the HadCM2 climate projections, alfalfa yields increased substantially in eastern regions and declined through the central part of the United States where temperature increases were projected to be larger and coupled with lower precipitation. Only slight increases in alfalfa yield were predicted for the western regions. Higher temperatures and consistent declines in precipitation over the next several decades are projected from the BMRC model, leading to declines in alfalfa yields across the United States. More moderate temperature increases along with higher precipitation projected from the UIUC model would result in modest yield increases throughout the central and western regions. Although there is substantial uncertainty in GCM projections of climate, these results underscore the significant impact that future precipitation patterns will have on alfalfa yields. Results from Table 1 show that yield changes were affected primarily by precipitation, followed by $\left[\mathrm{CO}_{2}\right]$, and temperature change. In these analyses, yields of alfalfa decreased by $1 \%$ for every $4 \mathrm{~mm}$ decrease in annual precipitation.

\section{Elevated [Carbon Dioxide] Effects on Ecosystem Interactions}

The ecology of grazinglands involves complex interactions between plants, large animal grazers, and soil biota that affect the acquisition, partitioning, and utilization of above- and belowground resources, all of which can modify projections based on our understanding of the physiological sensitivity of these ecosystems to elevated $\left[\mathrm{CO}_{2}\right]$ and climate change (Wilsey, 2001; Newton et al., 2006). For instance, exposure to high $\left[\mathrm{CO}_{2}\right]$ might be expected to increase plant regrowth if defoliation increases light levels to remaining leaves and thereby increases maximum photosynthetic rates (Harmens et al., 2004). However, although some experiments indicate that exposure to elevated $\left[\mathrm{CO}_{2}\right]$ enhances regrowth following defoliation (Harmens et al., 2004), other research shows no effect (Fajer et al., 1991; Newton et al., 2006) or even negative effects (Wilsey, 2001). Furthermore, Newton et al. (2006) observed different species and ecosystem-level responses of New Zealand pastures to elevated $\left[\mathrm{CO}_{2}\right]$ depending solely on whether the pastures had been grazed by sheep or merely hand defoliated, illustrating the challenge in understanding mechanisms underlying pastureland responses to rising $\left[\mathrm{CO}_{2}\right]$.

Elevated $\mathrm{CO}_{2}$ may also affect complex ecosystem interactions. One such interaction concerns the effects of endophyte infection and $\mathrm{N}$ fertilization on growth and chemical composition of tall fescue forage (Newman et al., 2003). Fescue plants grown with and without endophyte infection (Neotyphodium coenophialum) were placed in open chambers at either ambient $\left(350 \mu \mathrm{mol} \mathrm{mol}{ }^{-1}\right)$ or elevated $\left(700 \mu \mathrm{mol} \mathrm{mol}^{-1}\right)$ concentrations of $\mathrm{CO}_{2}$. Uniform rates of $\mathrm{P}$ and $\mathrm{K}$ were applied to all chambers and $\mathrm{N}$ fertilizer applied at two rates: 6.7 and $67.3 \mathrm{~g} \mathrm{~N} \mathrm{~m}^{-2}$. Elevated $\left[\mathrm{CO}_{2}\right]$ effects on plant growth were influenced by both the rate of $\mathrm{N}$ applied and the mutualistic relationship between tall fescue, as the host, and a fungus. The $\left[\mathrm{CO}_{2}\right]$ fertilization effect was enhanced in the presence of the endophyte fungus and $\mathrm{N}$ fertilization. Tiller appearance rates and accumulation of dry matter increased by at least $53 \%$ with elevated $\left[\mathrm{CO}_{2}\right]$ under even the low $\mathrm{N}$ treatment. In this study, Newman et al. (2003) also observed that elevated $\left[\mathrm{CO}_{2}\right]$ decreased forage lignin concentrations by $14 \%$, which is in contrast to the findings of previous studies (Fordham et al., 1997; Peñuelas and Estiarte, 1998). Recent studies by Bertrand et al. (2007, 2008a) have also highlighted the interaction between elevated $\left[\mathrm{CO}_{2}\right]$ and $\mathrm{N}$-fixing rhizobium in alfalfa for a number of crop processes.

\section{Rangelands Responses}

\section{Growing Season Length and Plant Phenology}

Many aspects of the ecology of rangelands are determined by the spatial and temporal distribution of precipitation and its effects on soil water availability (Campbell et al., 1997; Knapp et al., 2001; Morgan, 2005). Rising [ $\left.\mathrm{CO}_{2}\right]$, warming, and altered precipitation patterns will all impact soil water content and plant water relations (Morgan et al., 2004b; IPCC, 2007), so understanding their combined effects on the functioning of rangeland ecosystems is essential.

Rising temperatures should accelerate plant metabolism and developmental processes, cause an earlier onset of spring green-up, and ultimately result in an increase in the length of the growing season in rangelands; however, these responses will vary among species (Badeck et al., 2004). Warming effects will manifest in the changing of timing of phenological events (e.g., flowering and fruiting), as well as in overall lengthening of the growing season. In a controlled experiment, a continuous $2^{\circ} \mathrm{C}$ warming of the soil in a tallgrass prairie extended the growing season by $3 \mathrm{wk}$ (Wan et al., 2005). A similar warming experiment in California annual grassland advanced flowering of all but one annual species by 2 to $5 \mathrm{~d}$ (Cleland et al., 2006). An extreme event, 1-yr warming experiment in tallgrass prairie in which air temperatures in warmed plots were elevated more than $4^{\circ} \mathrm{C}$ above ambient, affected the timing of reproductive events, causing the spring blooming species to flower earlier and late blooming species to flower later (Sherry et al., 2007). The differential response among species to warming suggests there may be strong selection pressures that will alter rangeland community structure in response to further warming. These changes will potentially impact associated trophic levels that depend on these plant communities for important stages in their life cycles. Drought stress during the growing cycle may reduce the influence of warming on the rate of plant development (Gielen et al., 2005). The phenological response of herbaceous plants to rising $\left[\mathrm{CO}_{2}\right]$ will vary among species (Cleland et al., 2006; Huxman and Smith, 2001; Rae et al., 2006). The implications of rising temperature and $\left[\mathrm{CO}_{2}\right]$ for the phenologies of rangeland plants are not well understood or quantified. Thus, temperature is the primary climate driver that will determine growing season length and plant phenology, but precipitation variability and $\mathrm{CO}_{2}$ may cause deviations from the overall patterns expected from temperature alone.

\section{Elevated [Carbon Dioxide] Effects}

Most rangeland forage species possess either the $\mathrm{C}_{3}$ or $\mathrm{C}_{4}$ pathway for photosynthesis. Photosynthetic rates of $\mathrm{C}_{3}$ plants [which include most woody species and herbaceous broad-leaf species (forbs)] are not $\mathrm{CO}_{2}$-saturated at current $\left[\mathrm{CO}_{2}\right]$ and thus respond to changes in ambient $\left[\mathrm{CO}_{2}\right]$ (Drake et al., 1997). Conversely, photosynthesis in $\mathrm{C}_{4}$ plants (which includes many of the perennial rangeland grass species) is nearly $\mathrm{CO}_{2}$-saturated at current $\left[\mathrm{CO}_{2}\right]\left(390 \mu \mathrm{mol} \mathrm{mol}{ }^{-1}\right)$ when soil water is adequate. Some $\mathrm{C}_{4}$ species, however, do exhibit positive photosynthetic and growth responses to elevated $\left[\mathrm{CO}_{2}\right]$ (Polley 
et al., 2003). Herbaceous plants partially close stomata in response to increasing $\mathrm{CO}_{2}$ concentration, thereby reducing stomatal conductance to water and transpiration rates. This leads to improved plant water use efficiency (WUE), plant and soil water relations, and plant productivity under water limited conditions (Morgan et al., 2004b). These responses are as criti$\mathrm{cal}$ as the photosynthetic response in the cumulative effect of elevated $\left[\mathrm{CO}_{2}\right]$ on often water-limited rangelands.

Rangeland NPP has already responded to increases in $\left[\mathrm{CO}_{2}\right]$. The nearly $40 \%$ increase from preindustrial concentrations $\left(280-385 \mu \mathrm{mol} \mathrm{mol}^{-1}\right)$, increased aboveground NPP of mesic grassland in central Texas by 42 to $69 \%$ (Polley et al., 2003). A similar increase in biomass occurred when $\left[\mathrm{CO}_{2}\right]$ was increased from the current to an elevated concentration. Net primary productivity responses to elevated $\left[\mathrm{CO}_{2}\right]$ in most rangelands depend on precipitation and soil water availability. Experiments on the shortgrass steppe in Colorado and tall grass prairie in Kansas showed that NPP responds more to $\left[\mathrm{CO}_{2}\right]$ enrichment on the semiarid shortgrass steppe than subhumid prairie and, for a given ecosystem, during dry than wet years (Fig. 2). However, in a FACE experiment conducted in the arid Mojave Desert (Smith et al., 2000), increasing $\left[\mathrm{CO}_{2}\right]$ stimulated shrub growth more consistently during relatively wet years. Responses to $\left[\mathrm{CO}_{2}\right]$ enrichment are often not consistent between experiments. One open top chamber experiment found an increase in total biomass (aboveground + belowground) on annual grassland in California (Field et al., 1997); however, a subsequent FACE experiment at the same site found no response (Shaw et al., 2002).

\section{Temperature Effects}

Carbon dioxide enrichment is not the only climate change anticipated to affect rangeland NPP. Increasing ambient air and soil temperatures may enhance productivity under certain conditions; however, there are also potential negative effects of higher temperatures, particularly in dry and hot regions. Plant physiological processes are directly affected by temperature; rising ambient temperatures may increase the length of the growing season, increase soil $\mathrm{N}$ mineralization and availability, change soil water content, and cause shifts in species composition and community structure (Wan et al., 2005; Bertrand et al., 2008a). Biological processes are sensitive to plant temperatures and cause the direct effects of warming to vary within and among years, and among plant species. Growth rate and duration in high latitude and altitude rangelands is restricted due to severe cold temperatures; thus higher temperatures should stimulate yield. However, growth may be negatively affected by temperatures that are greater than what the high latitude species are adapted to (Bertrand et al., 2008b).

A $2^{\circ} \mathrm{C}$ increase in the daily minimum air temperature and mean soil temperature $(2.5 \mathrm{~cm}$ depth) in Oklahoma stimulated aboveground NPP of a tallgrass prairie by up to $19 \%$ during the first $3 \mathrm{yr}$ of a study by Wan et al. (2005). Increases in the rate of water loss associated with rising temperatures could reduce the positive effects of warming on production, but the importance of this interaction remains uncertain. While higher temperatures reduced the annual mean of soil water content in a tallgrass prairie (Wan et al., 2005), higher temperature increased soil water content in an annual grassland in California by accelerating senescence (Zavaleta et al., 2003).
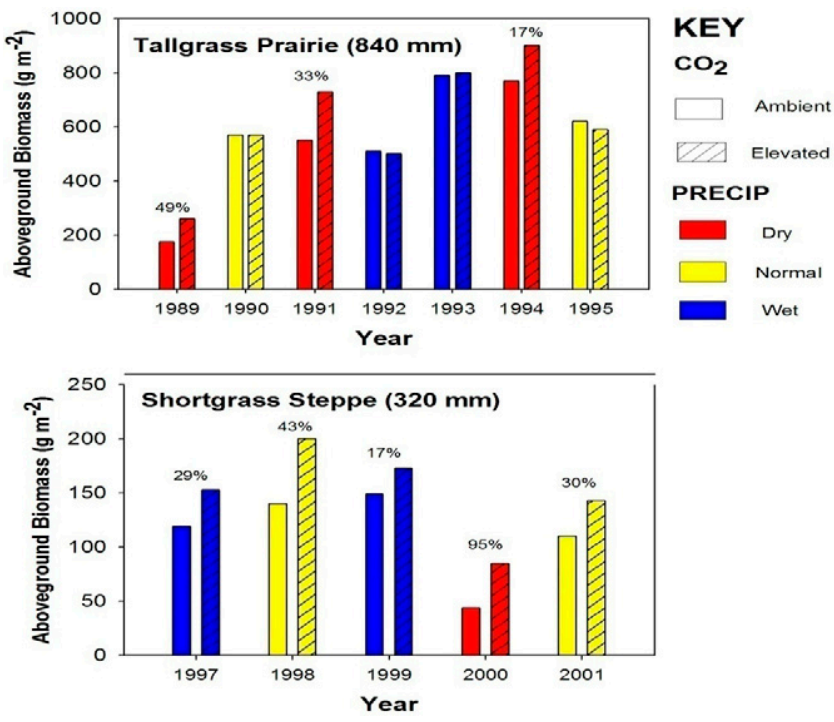

Fig. 2. Aboveground plant biomass harvested during summer at the approximate time of peak seasonal aboveground plant biomass from native Kansas tallgrass prairie (Owensby et al., 1999; 1989-1995) and Colorado Shortgrass steppe (Morgan et al., 2004a; 1997-200I). Vegetation was grown in similarlydesigned Open Top Chambers maintained at present Ambient (approximately $370 \mathrm{mmol} \mathrm{mol}^{-1} \mathrm{CO}_{2}$ in air; no cross-hatches) and Elevated (approximately $720 \mathrm{mmol} \mathrm{mol}^{-1} \mathrm{CO}_{2}$ in air; cross-hatches) atmospheric $\left[\mathrm{CO}_{2}\right]$. Histograms from different years are color-coded (red for dry; yellow for normal; blue for wet) according to the amount of annual precipitation received that particular year compared to long-term averages for the two sites, $840 \mathrm{~mm}$ for the tallgrass prairie and $320 \mathrm{~mm}$ for shortgrass steppe. When production increased at elevated $\left[\mathrm{CO}_{2}\right]$, the percentage increase is given within a year above the histogram. The involvement of water in the $\left[\mathrm{CO}_{2}\right]$ responses is seen in two ways; the relative plant biomass responses occur more commonly and in greater magnitude in the shortgrass steppe than in the tallgrass prairie, and the relative responses in both systems are greater in dry than wet years.

\section{Precipitation Effects}

Rangeland ecosystems will respond to changes in precipitation; however, the nature and magnitude of response is dependent on many geographic and physiologic variables. Nevertheless, some general trends can be found. When soil water is the predominant limiting resource for productivity, timing of precipitation can play an important role in regulating NPP. An experiment in a native tallgrass prairie ecosystem of northeastern Kansas found that increasing rainfall variability, with no change in total rainfall amounts, caused soil water content $(0-$ to $30-\mathrm{cm}$ depth) to be reduced and more variable, leading to an approximately 10\% reduction in aboveground NPP (Knapp et al., 2002; Fay et al., 2003), equal to the effect of a $30 \%$ reduction in rainfall amount. This reduction in productivity was a result of less productivity from subdominant graminoids. The direct effects of soil moisture deficits on root/shoot ratios, plant water status, and photosynthesis likely led to the reductions in aboveground NPP.

The seasonality of precipitation is also an important factor for NPP through its effects on locally-adapted species, which can differ depending on the particular ecosystem. Physiological adaptation to winter/early spring precipitation patterns in a system where reliable soil water recharge occurs before the growing season was found to affect NPP of herbaceous plants (Svejcar et al., 2003). The amount of early season precipitation also affects grasslands in the Northern Great Plains which are dominated by cool-season, 
$\mathrm{C}_{3}$ plant species that complete most of their growth by late spring to early summer. In such systems, NPP primarily depends on sufficient soil moisture at the beginning of the growing season (Heitschmidt and Haferkamp, 2003). In contrast, the warmseason $\mathrm{C}_{4}$ grass and oak (Quercus spp.) dominated savannas of the southwestern United States experience a strongly seasonal pattern of precipitation with a greater sensitivity to summer than winter precipitation (Weltzin and McPherson, 2003).

\section{MANAGEMENT IMPLICATIONS}

\section{Implications of Climate Change for Pasturelands}

This review has focused primarily on the biological responses of pasture and rangeland plant species and communities to changes in $\left[\mathrm{CO}_{2}\right]$, temperature and precipitation. In this section, we will consider the important consequences of these responses for the effective management of these agriculturally important ecosystems. Pasture productivity may increase as a result of projected increases in temperature and the associated lengthening of the growing season. Increased productivity, in turn, should benefit livestock production by reducing the need to store forage for winter feeding. However, higher temperatures may reduce forage production under some conditions, and $\left[\mathrm{CO}_{2}\right]$ and temperature changes will be accompanied by increased variation in precipitation that will, in turn, increase variability in grassland production. Thus, management responses must be flexible to accommodate such volatility and still maintain production at desired levels.

To design resilient management techniques, we need comprehensive medium to long-term studies that incorporate the likely effects of climate change on grazing regimes, mutualistic microbiological relationships (e.g., plant roots-nematodes; $\mathrm{N}$-fixing organisms), and biogeochemical cycling. Studies by Newton et al. (1996) and Wilsey (2001) demonstrate the value and scientific impacts obtained from multifactor experiments. To date, few studies use a comprehensive approach to address management adaptations needed to respond to changing climate. Nevertheless, analysis of the available literature does provide some insights. The inclusion of simulation modeling along with experimental hypotheses of ecosystem processes would prove valuable to land managers (Thornley and Cannell, 1997).

\section{Nutrient Cycle Feedbacks on Pastures}

The response of pastures to climate change will be influenced by grazing management. Thornley and Cannell (1997) found that the difficulty of realistically incorporating grazing into observational studies on plant responses to elevated temperature and $\left[\mathrm{CO}_{2}\right]$ prevents a full analysis of the effects of grazing on important ecosystem properties. However, using a modeling approach, they showed that grazing could significantly alter the response of pasturelands to climate change and $\mathrm{CO}_{2}$ by introducing changes in leaf-area dynamics, NPP, ecosystem C, and C/N ratios (Thornley and Cannell, 1997). In a later simulation study on grazed pastures, Thornley and Cannell (2000) found that changes in the mineral $\mathrm{N}$ pool and its turnover rate at elevated $\left[\mathrm{CO}_{2}\right]$ contribute to a slow increase in $\mathrm{C}$ content of plants and soils.

\section{Implications of Climate Change for Rangelands}

Rising $\left[\mathrm{CO}_{2}\right]$ has likely enhanced plant productivity on most rangelands over the past $150 \mathrm{yr}$ and will continue to do so over the next $30 \mathrm{yr}$. The magnitude of this response will depend on many factors, as discussed earlier in this paper. Simulation studies have projected increases in NPP for Great Plains native grasslands over the next $30 \mathrm{yr}$ in response to projected increases in $\left[\mathrm{CO}_{2}\right]$ and temperature (Pepper et al., 2005; Parton et al., 2007a). These simulation results are confirmed by experimental studies on shortgrass steppe (Morgan et al., 2004a). However, contrary results were obtained by Dukes et al. (2005) who found that California annual grassland production was minimally responsive to changes in $\left[\mathrm{CO}_{2}\right]$ or temperature. Uncertainty remains high in the outcome of the interactions of increased precipitation variability, rising $\left[\mathrm{CO}_{2}\right]$ and temperature, placing a severe constraint on predicting the effects of climate change on rangelands.

While prediction remains difficult, there is growing observational evidence that global climate changes are already affecting rangelands and associated ecosystems. Observations over the last century show that juniper trees in the arid West grew more than expected based on assessment of the climate impacts, an increase that may be attributable to increases in $\left[\mathrm{CO}_{2}\right]$ (Polley, 1997). Growth response of juniper to $\left[\mathrm{CO}_{2}\right]$ was greater during dry than wet years, consistent with the hypothesis that increased plant WUE due to $\mathrm{CO}_{2}$ enrichment stimulates plant growth more consistently during dry than wet years and to a greater extent in semiarid than mesic ecosystems (Morgan et al., 2004b), conditions that impart a growth advantage to deep-rooted woody vegetation (Polley, 1997; Morgan et al., 2007).

Plants with $\mathrm{C}_{3}$ photosynthesis, forbs and legumes show a positive response to rising $\left[\mathrm{CO}_{2}\right]$ and rising temperature; however, changes in soil water availability due to precipitation changes may temper the response of these functional groups (Polley, 1997; Morgan, 2005). Deep-rooted forbs and shrubs may be at an advantage under warming and rising $\left[\mathrm{CO}_{2}\right]$ because of the ability of their roots to access deep soil water (Polley et al., 2000; Bond and Midgley, 2000; Morgan et al., 2007). Predicted shifts in precipitation patterns toward wetter winters and drier summers in the desert southwest (IPCC, 2007; Wang, 2005) are expected to favor woody shrubs over herbaceous vegetation (Neilson, 1986) and may reinforce $\mathrm{CO}_{2}$-induced changes in plant community dynamics. In grasslands of the Northern Great Plains, where woody vegetation is currently sparse, enhanced winter precipitation may benefit the dominant cool-season, $\mathrm{C}_{3}$ grass species that rely on early-season soil moisture to complete most of their growth before late spring to early summer (Heitschmidt and Haferkamp, 2003). However, by itself, warmer temperature will tend to favor $\mathrm{C}_{4}$ species (Epstein et al., 2002b) by cancelling the $\mathrm{CO}_{2}$-advantage of $\mathrm{C}_{3}$ grasses in some rangelands.

The occurrence of species changes in rangelands may provide evidence that climate change is already affecting community structure. Encroachment of woody plants into grasslands remains one of the best examples of the combined effects of climate change and management in driving a species change that has had a tremendous negative impact on the range livestock industry. Mesquite (Prosopis glandulosa Torr.) and creosote (Larrea tridentate) bushes have replaced most of the former warm-season, perennial grasses in the southwestern arid and semiarid grasslands of the United States, while in the more mesic grasslands of the Central Great Plains trees and large shrubs are replacing $\mathrm{C}_{4}$ grasslands. While both of these changes are due to complex combinations of management (grazing and fire) 
and a host of environmental factors (Briggs et al., 2005; Peters et al., 2006), evidence is strong that rising $\left[\mathrm{CO}_{2}\right]$ and climate are important factors influencing these transitions (Briggs et al., 2005; Knapp et al., 2001; Morgan et al., 2007; Peters et al., 2006; Polley, 1997; Polley et al., 2003). Another example of the role of rising $\left[\mathrm{CO}_{2}\right]$ on community structure is the loss of woody species and spread of Bromus tectorum (cheatgrass) throughout the Intermountain region of western North America (Smith et al., 2000; Ziska et al., 2005). This shift in community structure has increased the frequency of wildfires and reduced establishment of perennial herbaceous species by changing soil water use patterns early in the growing season (Young, 1991).

\section{Nutrient Cycle Feedbacks in Rangelands}

Rangeland production is often limited by $\mathrm{N}$, and changing climate factors will likely affect the cycling between organic and inorganic N compounds. Plant material deposited on the soil surface or accumulated in the root zone is decomposed by soil fauna and micro flora and becomes part of the soil organic matter (SOM) pool (Fig. 3). Decomposition of SOM releases mineral and other plant-available forms of $\mathrm{N}$. Climate change and $\mathrm{CO}_{2}$ enrichment affect the plant functioning responsible for the rate of $\mathrm{N}$ release in the soil profile. Increasing temperatures, especially in the colder regions, will generally increase SOM decomposition (Reich et al., 2006b; Rustad et al., 2001); however, warming may limit microbial activity by causing more rapid soil drying or enhancing plant growth leading to faster rate of soil water use (Wan et al., 2005). In addition, decomposition processes can be affected by warming through the extension of the growing season (Wan et al., 2005). In water limited rangeland systems, soil water content will be the major factor leading to reductions in decomposition rates (Epstein et al., 2002a; Wan et al., 2005). Litter $\mathrm{N}$ concentration, coupled with temperature and water, are the dominant drivers of $\mathrm{N}$ release and immobilization dynamics (Parton et al., 2007a), while in arid rangeland systems surface litter decomposition dynamics are controlled through UV-stimulation of decomposition (Austin and Vivanco, 2006).

Rising $\left[\mathrm{CO}_{2}\right]$ does not directly affect soil microbial processes; however, there are indirect effects on soil micro flora and fauna. Luo et al. (2004) hypothesized that $\left[\mathrm{CO}_{2}\right]$ enrichment reduces plant-available $\mathrm{N}$ by stimulating plant growth and, thus, plant $\mathrm{N}$ uptake and $\mathrm{N}$ sequestration in long-lived plant biomass and $\mathrm{SOM}$ pools. The $\mathrm{N}$ accumulation in organic compounds eventually reduces the availability of soil $\mathrm{N}$ and ultimately limits plant growth response to $\left[\mathrm{CO}_{2}\right]$ or other climate changes (Reich et al., 2006a, 2006b; van Groenigen et al., 2006; Parton et al., 2007b). These responses involve a number of processes including increased biological fixation of $\mathrm{N}$, greater retention of atmospheric $\mathrm{N}$ deposition, reduced losses of $\mathrm{N}$ in gaseous or liquid forms, and more complete exploration of soil by expanded root systems (Luo et al., 2006). Compensation in rangeland ecosystems for temporary imbalances in $\mathrm{C}$ and $\mathrm{N}$ availability occurs by maximizing the amount of $\mathrm{C}$ retained per unit of $\mathrm{N}$. There are several reports demonstrating that $\mathrm{N}$ concentration of leaves or aboveground tissues has declined on shortgrass steppe, tallgrass prairie, and mesic grassland in response to increasing $\left[\mathrm{CO}_{2}\right]$, and on tallgrass prairie with warming, but total plant $\mathrm{N}$ uptake increases due to plant response to $\left[\mathrm{CO}_{2}\right]$ in these ecosystems and annual grasslands (Owensby et al., 1993; Hungate et al., 1997; King et al., 2004; Wan et al.,

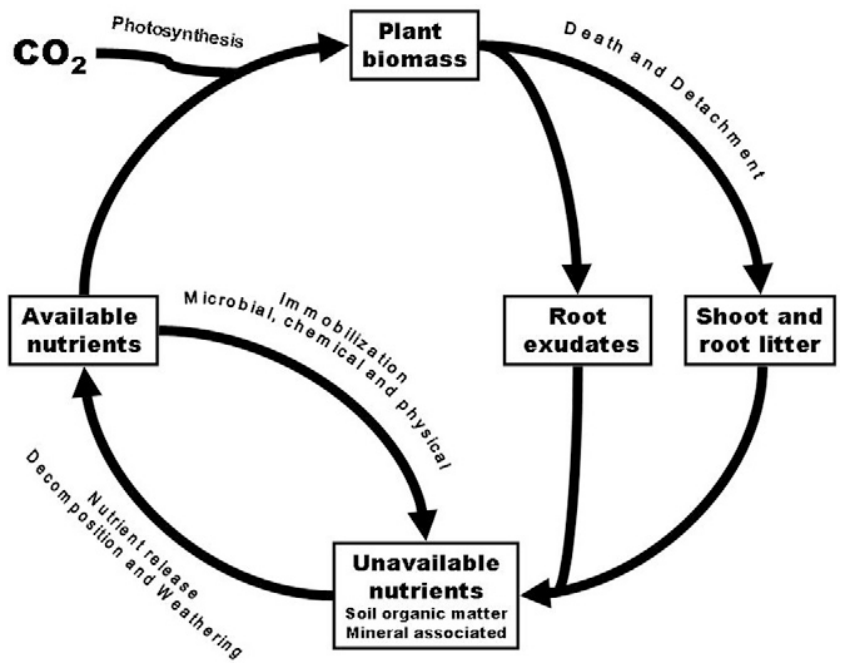

Fig. 3. Nutrient cycling feedbacks. While elevated $\left[\mathrm{CO}_{2}\right]$ may lead to increased photosynthesis and enhanced plant growth; the long-term response will depend on nutrient cycling feedbacks. Litter from decaying plants and root exudates enters a large soil nutrient pool that is unavailable to plants until they are broken down and released by microbial activity. Soil microbes may also fix available nutrients into new microbial biomass, thereby temporarily immobilizing them. The balance between these and other nutrient release and immobilization processes determines available nutrients and ultimate plant response. Source: Figure reprinted with permission from Science (Morgan, 2002).

2005; Gill et al., 2006). The degree to which N responds to rising $\left[\mathrm{CO}_{2}\right]$ is not known and potentially varies among ecosystems (Luo et al., 2006). These are important relationships to understand for rangeland management, as forage quality and soil $\mathrm{C}$ storage both strongly depend on available soil $\mathrm{N}$.

Nutrient cycling is sensitive to changes in plant species composition, which in turn is sensitive to global climate change. Shifts in the abundances or composition of species that differ in $\mathrm{C} / \mathrm{N}$ could affect element cycling (Weatherly et al., 2003; Allard et al., 2004; King et al., 2004; Dijkstra et al., 2006; Gill et al., 2006; Shaeffer et al., 2007). Increasing $\left[\mathrm{CO}_{2}\right]$ may reduce decomposition by altering the leaf litter $\mathrm{N}$ concentration (Gill et al., 2006); however, Norby et al. (2001) found that litter quality may not be the best predictor of tissue decomposition. Litter quality may be affected by changing species composition driven by rising $\left[\mathrm{CO}_{2}\right]$ and associated climatic changes (Murphy et al., 2002; Weatherly et al., 2003; Semmartin et al., 2004). Elevated $\left[\mathrm{CO}_{2}\right]$ and temperature changes may directly alter amounts and proportions of micro flora and fauna in the soil microfood web (e.g., Hungate et al., 2000; Sonnemann and Wolters, 2005), and/or the soil biota activity (Billings et al., 2004; Henry et al., 2005; Kandeler et al., 2006). Changes in microbial communities will have feedbacks on soil nutrient cycling and C storage; however, the extent of these impacts on microbes is relatively unclear (Niklaus et al., 2003; Ayers et al., 2008).

Simulation models incorporating decomposition dynamics have demonstrated that projected warming temperatures and rising $\left[\mathrm{CO}_{2}\right]$ throughout the next $100 \mathrm{yr}$ will stimulate plant production, but fail to agree on the soil $\mathrm{C}$ and $\mathrm{N}$ impact. A decrease in soil C stocks is predicted by the DayCent Model, while the Generic Decomposition and Yield Model (G'Day) estimates increasing soil C (Pepper et al., 2005). Nitrogen isotopes measurements obtained from herbarium specimens over 
Table 2. Potential changes in forage quality arising from atmospheric and climatic change.

\begin{tabular}{lll}
\hline \multicolumn{1}{c}{ Change } & Examples of positive effects on forage quality & \multicolumn{1}{c}{ Examples of negative effects on forage quality } \\
\hline $\begin{array}{l}\text { Life-form } \\
\text { distributions }\end{array}$ & $\begin{array}{l}\text { Decrease in proportion of woody shrubs and increase } \\
\text { in grasses in areas with increased fire frequency. }\end{array}$ & $\begin{array}{l}\text { Increase in the proportion of woody species because of elevated } \mathrm{CO}_{2}, \\
\text { increases in rainfall event sizes and longer intervals between rainfall events. }\end{array}$ \\
$\begin{array}{l}\text { Species or functional } \\
\text { group distributions }\end{array}$ & $\begin{array}{l}\text { Possible increase in } \mathrm{C}_{3} \text { grasses relative to } \mathrm{C}_{4} \text { grasses at Increase in the proportion of } \mathrm{C}_{4} \text { grasses relative to } \mathrm{C}_{3} \text { grasses at higher temper- } \\
\text { elevated } \mathrm{CO}_{2} .\end{array}$ & $\begin{array}{l}\text { atures. Increase in abundance of perennial forb species or perennial grasses of } \\
\text { low digestibility at elevated } \mathrm{CO}_{2} \text {. Increase in poisonous or weedy plants. }\end{array}$ \\
$\begin{array}{ll}\text { Plant biochemical } \\
\text { properties }\end{array}$ & $\begin{array}{l}\text { Increase in nonstructural carbohydrates at elevated } \\
\mathrm{CO}_{2} . \text { Increase in crude protein content of forage with } \\
\text { reduced rainfall. }\end{array}$ & $\begin{array}{l}\text { Decrease in crude protein content and digestibility of forage at elevated } \mathrm{CO}_{2} \\
\text { or higher temperatures. No change or decrease in crude protein in regions } \\
\text { with more summer rainfall. }\end{array}$ \\
\hline
\end{tabular}

the past hundred years show that rising $\left[\mathrm{CO}_{2}\right]$ is associated with increased $\mathrm{N}$ fixation and soil $\mathrm{N}$ mineralization, decreased soil $\mathrm{N}$ losses, and decreases in shoot $\mathrm{N}$ concentration (Peñuelas and Estiarte, 1997). The overall conclusion we can obtain from these evaluations is that soil $\mathrm{N}$ may constrain the responses of some terrestrial ecosystems to elevated $\left[\mathrm{CO}_{2}\right]$.

\section{FUTURE CHALLENGES \\ Redesigning Production Systems}

Given that the anticipated responses of pasturelands and rangelands to climate change are many, what are the most pressing challenges facing managers of these grazing lands? And, how can we prepare these lands to be more resilient to climate change? Many livestock production systems in the United States are resource intensive, requiring large inputs ranging from synthetic fertilizer applications to crops through to the transport of crops to animal feeding operations. The inefficient use of fuel is only one environmental problem associated with these systems; erosion and degradation of water supplies due to excessive nutrient inputs are also of concern. Conversion to integrated crop-livestock farming systems is one way to both reduce environmental impacts and improve the profitability and sustainability of livestock production systems, enhancing their ecological resilience to climate stressors (Russelle et al., 2007). Integrated crop-livestock system can have many forms such as the integration of grain crop production with perennial pastures and livestock operations. Integrated systems are likely to remain more productive in an increasingly variable climate, and are likely to retain greater biological diversity. Such diversified systems will likely experience fewer pests, diseases, and weeds, causing these agro-ecosystems to become more resilient and thus better able to adapt to climate change. Increasing the extent of perennial pastures would decrease nitrate leaching and soil erosion and reduce the synthetic $\mathrm{N}$ fertilizer requirements. This is not a suggestion for a return to the past. Rather, it would use traditional knowledge with advanced technical and planning tools.

\section{Maintaining and Improving Forage Quality}

Ruminants require forage with at least $7 \%$ crude protein (as a percentage of dietary dry matter) for maintenance, 10 to $14 \%$ protein for growth, and $15 \%$ protein for lactation (Ulyatt et al., 1980). Optimal rumen fermentation also requires a balance between available protein and energy. The rate at which digesta pass through the rumen decreases with increasing fiber content of forage, which reduces animal intake. Therefore, efficient animal production from pastureland and rangeland systems depends on both forage quality and quantity. The major quality parameters for forage in addition to fiber content and con- centrations of crude protein are nonstructural carbohydrates, minerals, and secondary toxic compounds.

Positive and negative changes in forage quality are possible as a result of atmospheric and climatic change when we examine the potential vegetation changes and environmental effects on forage protein, carbohydrate, and fiber contents (Table 2). Increasing $\left[\mathrm{CO}_{2}\right]$ causes nonstructural carbohydrates to increase (Read et al., 1997) thereby leading to potential improvements in forage quality (Brito et al., 2008). However, the effect is expected to vary among forage species. Environments with increased $\left[\mathrm{CO}_{2}\right]$ often cause plant $\mathrm{N}$ and crude protein concentrations to decline, offsetting the positive effects of $\left[\mathrm{CO}_{2}\right]$ increases on plant production and carbohydrates (Cotrufo et al., 1998; Milchunas et al., 2005). There is limited evidence that suggests the decline is enhanced when soil $\mathrm{N}$ availability is low rather than high (Bowler and Press, 1996; Wilsey, 1996), with the overall implication that rising $\left[\mathrm{CO}_{2}\right]$ reduces the digestibility of forages already of poor quality for ruminants. Warming temperatures reduce tissue $\mathrm{N}$ concentrations (Wan et al., 2005), while reductions in precipitation have the opposite effect. Reductions in forage quality could have pronounced negative effects on animal growth, reproduction, and mortality (Milchunas et al., 2005; Owensby et al., 1996), and could create an unsustainable livestock production system unless animal diets are supplemented with $\mathrm{N}$ (e.g., urea, soybean meal). As one example for a shortgrass steppe, increasing $\left[\mathrm{CO}_{2}\right]$ reduced the crude protein concentration of autumn forage below critical maintenance levels for livestock in 3 out of $4 \mathrm{yr}$ and reduced the digestibility of forage by $14 \%$ in mid-season and by $10 \%$ in autumn (Milchunas et al., 2005). The grass most favored by $\left[\mathrm{CO}_{2}\right]$ enrichment, exhibited the lowest crude protein concentration. Regrowth of plant tissues following defoliation generally show higher quality than older tissue, so defoliation could reduce the negative effects of $\left[\mathrm{CO}_{2}\right]$ on forage quality but this effect was not evident on shortgrass steppe (Milchunas et al., 2005). We should not expect that the changes in life forms, species, or functional groups resulting from global climate change will be consistent among pasturelands or rangelands (Table 3).

\section{SUMMARY}

In this paper, we examined possible impacts of climate change on pasturelands and rangelands in the United States during the next five decades. A warming of 1.5 to $2^{\circ} \mathrm{C}$ and a slight increase in precipitation are projected this period; however, these effects are highly uncertain and are not expected to be uniform over U.S. pasture and rangelands. Pasture and rangeland species responses to climate change will be complex because the major climatic drivers $\left(\mathrm{CO}_{2}\right.$ concentration, temperature, and precipitation) interact with plant and management factors in complex and still poorly understood ways. In general, the response of 
Table 3. Carbon dioxide and climate change responses and management options for grazing land factors.

\begin{tabular}{|c|c|c|}
\hline Factor & Responses to rising $\mathrm{CO}_{2}$ and climate change & Management options \\
\hline Primary production & $\begin{array}{l}\text { Increase or little change with rising } \mathrm{CO}_{2} \text { :Applies to most systems, especially water-limited } \\
\text { rangelands. Nitrogen may limit } \mathrm{CO}_{2} \text { response in some systems. } \\
\text { Increases or little change with temperature: Applies to most temperate and wet systems. } \\
\text { Decreases with temperature: Applies to arid and semiarid systems that experience } \\
\text { significantly enhanced evapotranspiration and drought, particularly where precipitation } \\
\text { is not expected to increase. } \\
\text { Variable responses with precipitation: Depends on present climate, and nature of precipi- } \\
\text { tation change. Increases in production in regions where water is limiting, but increasing } \\
\text { temperatures and more intense precipitation events will reduce this. }\end{array}$ & $\begin{array}{l}\text { Adjust forage harvesting: } \\
\text { Stocking rates. } \\
\text { Grazing systems. } \\
\text { Mowing practices (productive grasslands). } \\
\text { Develop and use adapted forage species (e.g. } \\
\text { legumes, } \mathrm{C}_{4} \text { grasses where appropriate, more } \\
\text { drought-resistant species and cultivars). } \\
\text { Enterprise change (e.g. movement to more or less } \\
\text { intensive agricultural practices). }\end{array}$ \\
\hline $\begin{array}{l}\text { Plant community } \\
\text { species composition }\end{array}$ & $\begin{array}{l}\text { Global changes will drive competitive responses that alter plant communities: In } \\
\text { some systems, legumes and } \mathrm{C}_{3} \text { species may be favoured in future } \mathrm{CO}_{2}-\text { enriched } \\
\text { environments, but community reactions will be variable and highly site specific. } \\
\text { Warmer environments will favour } \mathrm{C}_{4} \text { metabolisms. Both productive and reproduc- } \\
\text { tive responses will be featured in community changes. Ultimate plant community } \\
\text { responses will probably reflect alterations in soil nutrients and water, and involve } \\
\text { complex interactions between changes in } \mathrm{CO}_{2} \text {, temperature and precipitation. Weed } \\
\text { invasions may already be underway, due to rising atmospheric } \mathrm{CO}_{2} \text {. Proximity to } \\
\text { urban areas will add complex interactions with ozone and } \mathrm{N} \text { deposition. }\end{array}$ & $\begin{array}{l}\text { All of the above. } \\
\text { Weed control: } \\
\text { Fire management and/or grazing practices to } \\
\text { convert woody lands to grasslands. } \\
\text { Herbicides where appropriate to control } \\
\text { undesirables. } \\
\text { Enterprise change or emphasis: } \\
\text { Change between intensive/extensive practices. } \\
\text { C storage strategy. } \\
\text { Tourism, hunting, wildlife. } \\
\text { Biodiversity. }\end{array}$ \\
\hline Forage quality & $\begin{array}{l}\text { Increasing } \mathrm{CO}_{2} \text { will alter forage quality. In productive grasslands with ample } \mathrm{N} \text {, } \\
\text { forage quality may increase due to more TNC. In } \mathrm{N} \text {-limited native systems, } \\
\mathrm{CO}_{2} \text {-induced reduction in } \mathrm{N} \text { and increased fiber may lower quality. }\end{array}$ & $\begin{array}{l}\text { Use/interseed legumes where } \mathrm{N} \text { is limiting and } \\
\text { practice is feasible. } \\
\text { Fertilize where feasible. } \\
\text { Alter supplemental feeding practices. }\end{array}$ \\
\hline
\end{tabular}

pasture species to increasing $\left[\mathrm{CO}_{2}\right]$ is expected to be consistent with the $\mathrm{CO}_{2}$ response of $\mathrm{C}_{3}$ and $\mathrm{C}_{4}$ crop species, although significant exceptions may occur. Uncertainty in the future projections of precipitation and temperature change preclude the design of specific land management adaptation options at this time. Generally, increases in $\left[\mathrm{CO}_{2}\right]$ and precipitation will enhance rangeland NPP, whereas increased air temperatures will either increase or decrease NPP, but there will be surprises and regional differences. We suggest that diversified crop-livestock productions systems would provide increased resilience to conditions of higher $\left[\mathrm{CO}_{2}\right]$, higher temperatures (to an uncertain degree), and uncertain precipitation changes, and therefore help ensure pasture and rangeland production under future climates. To prepare for this, we suggest that researchers include grazing treatments together with assessments of mutualistic relationships (e.g., plant roots-nematodes; $\mathrm{N}$-fixing organisms) and the cycling of $\mathrm{C}$, essential nutrient elements, and water in climate change experiments on pasture and rangeland ecosystems.

\section{REFERENCES}

Ainsworth, E.A., and S.P. Long. 2005. What have we learned from 15 years of free-air $\mathrm{CO}_{2}$ enrichment (FACE)? A meta-analytic review of the responses of photosynthesis, canopy properties and plant production to rising $\mathrm{CO}_{2}$. New Phytol. 165:351-371.

Allard, V., P.C.D. Newton, M. Lieffering, J.F. Soussana, P. Grieu, and C. Matthews. 2004. Elevated $\mathrm{CO}_{2}$ effects on decomposition processes in a grazed grassland. Glob. Change Biol. 10:1553-1564.

Amthor, J. 2001. Effects of atmospheric $\mathrm{CO}_{2}$ concentration on wheat yield: Review of results from experiments using various approaches to control $\mathrm{CO}_{2}$ concentration. Field Crops Res. 73:1-34.

Austin, A.T., and L. Vivanco. 2006. Plant litter decomposition in a semi-arid ecosystem controlled by photodegradation. Nature (London) 442:555-558.

Ayers, E., D.H. Wall, B.L. Simmons, C.B. Field, J. Roy, D. Milchunas, and J.A. Morgan. 2008. Belowground grassland herbivores are surprisingly resistant to elevated atmospheric $\mathrm{CO}_{2}$ concentrations. Soil Biol. Biochem. 40:978-985.

Badeck, F.W., A. Bondeau, K. Bottcher, D. Doktor, W. Lucht, J. Schaber, and S. Sitch. 2004. Responses of spring phenology to climate change. New Phytol. 162:295-309.

Bertrand, A., D. Prévost, F.J. Bigras, and Y. Castonguay. 2007. Elevated atmospheric $\mathrm{CO}_{2}$ and strain of rhizobium alter freezing tolerance and cold- induced molecular changes in alfalfa (Medicago sativa L.). Ann. Bot. (London) 99:275-284.

Bertrand, A., D. Prévost, F.J. Bigras, R. Lalande, G.F. Tremblay, Y. Castonguay, and G. Bélanger. 2008a. Alfalfa response to elevated $\mathrm{CO}_{2}$ varies with the symbiotic rhizobial strain. Plant Soil 301:173-187.

Bertrand, A., G.F. Tremblay, S. Pelletier, Y. Castonguay, and G. Bélanger. 2008b. Yield and nutritive value of timothy as affected by temperature, photoperiod and time of harvest. Grass Forage Sci. 63:421-432.

Billings, S.A., S.M. Schaeffer, and R.D. Evans. 2004. Soil microbial activity and $\mathrm{N}$ availability with elevated $\mathrm{CO}_{2}$ in Mojave Desert soils. Global Biogeochem. Cycles 18:GA1011 10.1029/2003GB002137.

Bond, W.J., and G.F. Midgley. 2000. A proposed $\mathrm{CO}_{2}$-controlled mechanism of woody plant invasion in grasslands and savannas. Glob. Change Biol. 6:865-869.

Bowler, J.M., and M.C. Press. 1996. Effects of elevated $\mathrm{CO}_{2}$, nitrogen form and concentration on growth and photosynthesis of a fast- and slowgrowing grass. New Phytol. 132:391-401.

Briggs, J.M., A.K. Knapp, J.M. Blair, J.L. Heisler, G.A. Hoch, M.S. Lett, and J.K. McCarron. 2005. An ecosystems in transition: Causes and consequences of the conversion of mesic grassland to shrubland. Bioscience 55:243-254.

Brito, A.F., G.F. Tremblay, A. Bertrand, Y. Castonguay, G. Bélanger, R. Michaud, H. Lapierre, C. Benchaar, H.V. Petit, D.R. Ouellet, and R. Berthiaume. 2008. Alfalfa cut at sundown and harvested as baleage improves milk yield of late-lactation dairy cows. J. Dairy Sci. 91:3968-3982.

Campbell, B.D., D.M. Stafford Smith, and G.M. McKeon. 1997. Elevated $\mathrm{CO}_{2}$ and water supply interactions in grasslands: A pastures and rangelands management perspective. Glob. Change Biol. 3:177-187.

Cleland, E.E., N.R. Chiariello, S.P. Loarie, H.A. Mooney, and C.B. Field. 2006. Diverse responses of phenology to global changes in a grassland ecosystem. Proc. Natl. Acad. Sci. USA 103:13740-13744.

Cotrufo, M.F., P. Ineson, and A. Scott. 1998. Elevated $\mathrm{CO}_{2}$ reduces the nitrogen concentration of plant tissues. Glob. Change Biol. 4:43-54.

Dijkstra, F.A., S.E. Hobbie, and P. Reich. 2006. Soil processes affected by sixteen grassland species grown under different environmental conditions. Soil Sci. Soc. Am. J. 70:770-777.

Drake, B.G., M.A. Gonzalez-Meler, and S.P. Long. 1997. More efficient plants: A consequence of rising atmospheric $\mathrm{CO}_{2}$ ? Annu. Rev. Plant Physiol. Plant Mol. Biol. 48:609-639.

Dukes, J.S., N.R. Chiariello, E.E. Cleland, L.A. Moore, M.R. Shaw, S. Thayer T. Tobeck, H.A. Mooney, and C.B. Field. 2005. Responses of grassland production to single and multiple global environmental changes. PLoS Biol. 3:1829-1837.

Epstein, H.E., I.C. Burke, and W.K. Lauenroth. 2002a. Regional patterns of decomposition and primary production rates in the U.S. Great Plains. Ecology 83:320-327. 
Epstein, H.E., R.A. Gill, J.M. Paruelo, W.K. Lauenroth, G.J. Jia, and I.C. Burke. 2002b. The relative abundance of three plant functional types in temperature grasslands and shrublands of North and South America: Effects of projected climate change. J. Biogeogr. 29:875-888.

Fajer, E.D., M.D. Bowers, and F.A. Bazzaz. 1991. Performance and allocation patterns of the perennial herb, Plantago lanceolata, in response to simulated herbivory and elevated $\mathrm{CO}_{2}$ environments. Oecologia 87:37-42.

Fay, P.A., J.D. Carlisle, A.K. Knapp, J.M. Blair, and S.L. Collins. 2003. Productivity responses to altered rainfall patterns in a $\mathrm{C}_{4}$-dominated grassland. Oecologia 137:245-251.

Field, C.B., C.P. Lund, N.R. Chiariello, and B.E. Mortimer. 1997. $\mathrm{CO}_{2}$ effects on the water budget of grassland microcosm communities. Glob. Change Biol. 3:197-206.

Fordham, M., J.D. Barnes, I. Bettarini, A. Polle, N. Slee, C. Raines, F. Miglietta, and A. Raschi. 1997. The impact of elevated $\mathrm{CO}_{2}$ on growth and photosynthesis in Agrostis canina L. ssp. monteluccii adapted to contrasting atmospheric $\mathrm{CO}_{2}$ concentrations. Oecologia 110:169-178.

Gielen, B., H.J. De Boeck, C.M.H.M. Lemmens, R. Valcke, I. Nijs, and R. Ceulemans. 2005. Grassland species will not necessarily benefit from future elevated air temperatures: A chlorophyll fluorescence approach to study autumn physiology. Physiol. Plant. 125:52-63.

Gill, R.A., L.J. Anderson, H.W. Polley, H.B. Johnson, and R.B. Jackson. 2006. Potential nitrogen constraints on soil carbon sequestration under low and elevated atmospheric $\mathrm{CO}_{2}$. Ecology 87:41-52.

Greer, D.H., W.A. Laing, and B.D. Campbell. 1995. Photosynthetic responses of thirteen pasture species to elevated $\mathrm{CO}_{2}$ and temperature. Aust. J. Plant Physiol. 22:713-722.

Harmens, H., P.D. Williams, S.L. Peters, M.T. Banbrick, A. Hopkins, and T.W. Ashenden. 2004. Impacts of elevated atmospheric $\mathrm{CO}_{2}$ and temperature on plant community structure of a temperate grassland as modulated by cutting frequency. Grass Forage Sci. 59:144-156.

Hatfield, J.L., K.J. Boote, P. Fay, L. Hahn, C. Izaurralde, B.A. Kimball, T. Mader, J. Morgan, D. Ort, W. Polley, A. Thomson, and D. Wolfe. 2008. Agriculture. In The effects of climate change on agriculture, land resources, water resources, and biodiversity in the United States. U.S. Climate Change Science Program and the Subcommittee on Global Change Res., Washington, DC.

Hatfield, J.L., K.J. Boote, B.A. Kimball, L. Ziska, R.C. Izaurralde, D. Ort, A.M. Thomson, and D.A. Wolfe. 2011. Climate impacts on agriculture: Implications for crop production. Agron. J. $\mathrm{xx}: \mathrm{xx}-\mathrm{xx}$ (this issue).

Heitschmidt, R.K., and M.R. Haferkamp. 2003. Ecological consequences of drought and grazing on grasslands of the northern Great Plains. p. 107126. In J.F. Weltzin and G.R. McPherson (ed.) Changing precipitation regimes and terrestrial ecosystems. Univ. of Arizona Press, Tucson.

Henry, H.A.L., J.D. Juarez, C.B. Field, and P.M. Vitousek. 2005. Interactive effects of elevated $\mathrm{CO}_{2}, \mathrm{~N}$ deposition and climate change on extracellular enzyme activity and soil density fractionation in a California annual grassland. Glob. Change Biol. 11:1808-1815.

Hungate, B.A., F.S. Chapin, III, H. Zhong, E.A. Holland, and C.B. Field. 1997. Stimulation of grassland nitrogen cycling under carbon dioxide enrichment. Oecologia 109:149-153.

Hungate, B.A., C.H. Jaeger, III, G. Gamara, F.S. Chapin, III, and C.B. Field. 2000. Soil microbiota in two annual grasslands: Responses to elevated atmospheric $\mathrm{CO}_{2}$. Oecologia 124:589-598.

Huxman, T.E., and S.D. Smith. 2001. Photosynthesis in an invasive grass and native forb at elevated $\mathrm{CO}_{2}$ during an El Nino year in the Mojave Desert. Oecologia 128:193-201.

IPCC. 2007. Summary for policymakers. In S. Solomon et al. (ed.) Climate change 2007: The physical science basis. Contribution of Working Group I to the Fourth Assessment Report of the Intergovernmental Panel on Climate Change. Cambridge Univ. Press, New York.

Izaurralde, R.C., N.J. Rosenberg, R.A. Brown, and A.M. Thomson. 2003. Integrated assessment of Hadley Centre climate change projections on water resources and agricultural productivity in the conterminous United States. II. Regional agricultural productivity in 2030 and 2095. Agric. For. Meteorol. 117:97-122.

Jablonski, L.M., X.Z. Wang, and P.S. Curtis. 2002. Plant reproduction under elevated $\mathrm{CO}_{2}$ conditions: A meta-analysis of reports on 79 crop and wild species. New Phytol. 156:9-26.

Kandeler, E., A.R. Mosier, J.A. Morgan, D.G. Milchunas, J.Y. King, S. Rudolph, and D. Tscherko. 2006. Response of soil microbial biomass and enzyme activities to the transient elevation of carbon dioxide in a semiarid grassland. Soil Biol. Biochem. 38:2448-2460.

Kimball, B.A. 1983. Carbon dioxide and agricultural yield. An assemblage of 430 prior observations. Agron. J. 75:779-788.

Kimball, B.A., K. Kobayashi, and M. Bindi. 2002. Responses of agricultural crops to free-air $\mathrm{CO}_{2}$ enrichment. Adv. Agron. 77:293-368.

King, J.Y., A.R. Mosier, J.A. Morgan, D.R. LeCain, D.G. Milchunas, and W.J. Parton. 2004. Plant nitrogen dynamics in shortgrass steppe under elevated atmospheric carbon dioxide. Ecosystems 7:147-160.

Knapp, A.K., J.M. Briggs, and J.K. Koelliker. 2001. Frequency and extent of water limitation to primary production in a mesic temperate grassland. Ecosystems 4:19-28.

Knapp, A.K., P.A. Fay, J.M. Blair, S.L. Collins, M.D. Smith, J.D. Carlisle, C.W. Harper, B.T. Danner, M.S. Lett, and J.K. McCarron. 2002. Rainfall variability, carbon cycling, and plant species diversity in a mesic grassland. Science (Washington, DC) 298:2202-2205.

Long, S.P., E.A. Ainsworth, A.D.B. Leakey, J. Nösberger, and D.R. Ort. 2006. Food for thought: Lower-than-expected crop yield stimulation with rising $\mathrm{CO}_{2}$ concentrations. Science (Washington, DC) 312:1918-1921.

Luo, Y., D. Hui, and D. Zhang. 2006. Elevated $\mathrm{CO}_{2}$ stimulate net accumulations of carbon and nitrogen in land ecosystems: A meta-analysis. Ecology 87:53-63.

Luo, Y., B. Su, W.S. Currie, J.S. Dukes, A. Finzi, U. Hartwig, B. Hungate, R.E. McMurtrie, R. Oren, W.J. Parton, D.E. Pataki, M.R. Shaw, D.R. Zak, and C.B. Field. 2004. Progressive nitrogen limitation of ecosystem responses to rising atmospheric carbon dioxide. Bioscience 54:731-739.

Milchunas, D.G., A.R. Mosier, J.A. Morgan, D.R. LeCain, J.Y. King, and J.A. Nelson. 2005. Elevated $\mathrm{CO}_{2}$ and defoliation effects on a shortgrass steppe: Forage quality versus quantity for ruminants. Agric. Ecosyst. Environ. 111:166-184.

Morgan, J.A. 2002. Looking beneath the surface. Science (Washington, DC) 298:1903-1904.

Morgan, J.A. 2005. Rising atmospheric $\mathrm{CO}_{2}$ and global climate change: Management implications for grazing lands. p. 245-272. In S.G. Reynolds and J. Frame (ed.) Grasslands: Developments opportunities perspectives. Science Publ., Enfield, NH.

Morgan, J.A., D.G. Milchunas, E.D.R. LeCain, M.S. West, and A.R. Mosier. 2007. Carbon dioxide enrichment alters plant community structure and accelerates shrub growth in the shortgrass steppe. Proc. Natl. Acad. Sci. USA 104:14724-14729.

Morgan, J.A., A.R. Mosier, D.G. Milchunas, D.R. LeCain, J.A. Nelson, and W.J. Parton. 2004a. $\mathrm{CO}_{2}$ enhances productivity, alters species composition, and reduces digestibility of shortgrass steppe vegetation. Ecol. Appl. 14:208-219.

Morgan, J.A., D.E. Pataki, C. Körner, H. Clark, S.J. Del Grosso, J.M. Grünzweig, A.J. Knapp, A.R. Mosier, P.C.D. Newton, P.A. Niklaus, J.B. Nippert, R.S. Nowak, W.J. Parton, H.W. Polley, and M.R. Shaw. 2004b. Water relations in grassland and desert ecosystems exposed to elevated atmospheric $\mathrm{CO}_{2}$. Oecologia 140:11-25.

Murphy, K.L., I.C. Burke, M.A. Vinton, W.K. Lauenroth, M.R. Aguiar, D.A. Wedin, R.A. Virginia, and P.N. Lowe. 2002. Regional analysis of litter quality in the central grassland region of North America.J. Veg. Sci. 13:395-402.

Neilson, R.P. 1986. High-resolution climatic analysis and southwest biogeography. Science (Washington, DC) 232:27-34.

Newman, J.A., M.L. Abner, R.G. Dado, D.J. Gibson, A. Brookings, and A.J. Parsons. 2003. Effects of elevated $\mathrm{CO}_{2}$, nitrogen and fungal endophyteinfection on tall fescue: Growth, photosynthesis, chemical composition and digestibility. Glob. Change Biol. 9:425-437.

Newton, P.C.D., V. Allard, R.A. Carran, and M. Lieffering. 2006. Impacts of elevated $\mathrm{CO}_{2}$ on a grassland grazed by sheep: The New Zealand FACE experiment. p. 157-171. In J. Nösberger et al. (ed.) Managed ecosystems and $\mathrm{CO}_{2}$ : Case studies, processes, and perspectives. Springer-Verlag, Berlin.

Newton, P.C.D., H. Clark, C.C. Bell, and E.M. Glasgow. 1996. Interaction of soil moisture and $\mathrm{CO}_{2}$ on the above-ground growth rate, root length density, and gas exchange of turves from temperature pastures. J. Exp. Bot. 47:771-779.

Newman, Y.C., L.E. Sollenberger, K.J. Boote, L.H. Allen, Jr., and R.C. Littell. 2001. Carbon dioxide and temperature effects on forage dry matter production. Crop Sci. 41:399-406.

Niklaus, P.A., J. Alphei, D. Ebersberger, C. Kampichlers, E. Kandeler, and D. Tscherko. 2003. Six years of in situ $\mathrm{CO}_{2}$ enrichment evoke changes in soil structure and soil biota of nutrient-poor grassland. Glob. Change Biol. 9:585-600. 
Norby, R.J., M.F. Cortufo, P. Ineson, E.G.O. Neill, and J.G. Canadell. 2001. Elevated $\mathrm{CO}_{2}$, litter chemistry, and decomposition: A synthesis. Oecologia 127:153-165.

Owensby, C.E., R.C. Cochran, and L.M. Auen. 1996. Effects of elevated carbon dioxide on forage quality for ruminants. p. 363-371. In Ch. Körner and F.A. Bazzaz (ed.) Carbon dioxide, populations and communities. Academic Press, San Diego, CA.

Owensby, C.E., P.I. Coyne, and L.M. Auen. 1993. Nitrogen and phosphorus dynamics of a tallgrass prairie ecosystem exposed to elevated carbon dioxide. Plant Cell Environ. 16:843-850.

Owensby, C.E., J.M. Ham, A.K. Knapp, and L.M. Auen. 1999. Biomass production and species composition change in a tallgrass prairie ecosystem after long-term exposure to elevated atmospheric $\mathrm{CO}_{2}$. Glob. Change Biol. 5:497-506.

Parton, W., W.L. Silver, I.C. Burke, L. Grassens, M.E. Harmon, W.S. Currie, J.Y. King, E.C. Adair, L.A. Brandt, S.C. Hart, and B. Fasth. 2007a. Global-scale similarities in nitrogen release patterns during long-term decomposition. Science (Washington, DC) 315:361-364.

Parton, W.J., J.A. Morgan, G. Wang, and S.J. Del Grosso. 2007b. Projected ecosystem impact of the prairie heating and $\mathrm{CO}_{2}$ enrichment experiment. New Phytol. 174:823-834.

Peñuelas, J., and M. Estiarte. 1997. Trends in plant carbon concentration and plant demand for $\mathrm{N}$ throughout this century. Oecologia 109:69-73.

Peñuelas, J., and M. Estiarte. 1998. Can elevated $\mathrm{CO}_{2}$ affect secondary metabolism and ecosystem function? Trends Ecol. Evol. 13:20-24.

Pepper, D.A., S.J. Del Grosso, R.E. McMurtrie, and W.J. Parton. 2005. Simulated carbon sink response of shortgrass steppe, tallgrass prairie and forest ecosystems to rising $\left[\mathrm{CO}_{2}\right]$, temperature and nitrogen input. Global Biogeochem. Cycles 19:GB1004 10.1029/2004GB002226.

Peters, D.P.C., B.T. Bestelmeyer, J.E. Herrick, E.L. Fredickson, H.C. Monger, and K.M. Havstad. 2006. Disentangling complex landscapes: New insights into arid and semiarid system dynamics. Bioscience 56:491-501.

Polley, H.W. 1997. Implications of rising atmospheric carbon dioxide for rangelands. J. Range Manage. 50:561-577.

Polley, H.W., H.B. Johnson, and J.D. Derner. 2003. Increasing $\mathrm{CO}_{2}$ from subambient to superambient concentrations alters species composition and increases above-ground biomass in a $\mathrm{C}_{3} / \mathrm{C}_{4}$ grassland. New Phytol. 160:319-327.

Polley, H.W., J.A. Morgan, B.D. Campbell, and M. Stafford Smith. 2000. Crop ecosystem responses to climatic change: Rangelands. p. 293-314. In K.R. Reddy and H.F. Hodges (ed.) Climate change and global crop productivity. CABI, Wallingford, Oxon, UK.

Rae, A.M., R. Ferris, M.J. Tallis, and G. Taylor. 2006. Elucidating genomic regions determining enhanced leaf growth and delayed senescence in elevated $\mathrm{CO}_{2}$. Plant Cell Environ. 29:1730-1741.

Read, J.J., J.A. Morgan, N.J. Chatterton, and P.A. Harrison. 1997. Gas exchange and carbohydrate and nitrogen concentrations in leaves of Pascopyrum smithii $\left(\mathrm{C}_{3}\right)$ and Bouteloua gracilis $\left(\mathrm{C}_{4}\right)$ at different carbon dioxide concentrations and temperatures. Ann. Bot. (London) 79:197-206.

Reich, P.B., S.E. Hobbie, T. Lee, D.S. Ellsworth, J.B. West, D. Tilman, J.M.H. Knops, S. Naeem, and J. Trost. 2006a. Nitrogen limitation constrains sustainability of ecosystem response to $\mathrm{CO}_{2}$. Nature (London) 440:922-924.

Reich, P.B., B.A. Hungate, and Y. Luo. 2006b. Carbon-nitrogen interactions in terrestrial ecosystems in response to rising atmospheric carbon dioxide. Annu. Rev. Ecol. Syst. 37:611-636.

Russelle, M.P., M.H. Entz, and A.J. Franzluebbers. 2007. Reconsidering integrated crop-livestock systems in North America. Agron. J. 99:325-334.

Rustad, L.E., J.L. Campbell, G.M. Marion, R.J. Norby, M.J. Mitchell, A.E. Hartley, J.H.C. Cornelissen, and J. Gurevitch. 2001. A meta-analysis of the response of soil respiration, net nitrogen mineralization, and aboveground plant growth to experimental ecosystem warming. Oecologia 126:543-562.

Schwartz, M.D., R. Ahas, and A. Aasa. 2006. Onset of spring starting earlier across the Northern Hemisphere. Glob. Change Biol. 12:343-351.

Semmartin, M., M.R. Aguiar, R.A. Distel, A.S. Moretto, and C.M. Ghersa. 2004. Litter quality and nutrient cycling affected by grazing-induced species replacements along a precipitation gradient. Oikos 107:148-160.

Shaeffer, S.M., S.A. Billings, and R.D. Evans. 2007. Laboratory incubations reveal potential responses of soil nitrogen cycling in soil $\mathrm{C}$ and $\mathrm{N}$ availability in Mojave Desert soils exposed to elevated atmospheric $\mathrm{CO}_{2}$. Glob. Change Biol. 13:1-12.

Shaw, M.R., E.S. Zavaleta, N.R. Chiariello, E.E. Cleland, H.A. Mooney, and C.B. Field. 2002. Grassland responses to global environmental changes suppressed by elevated $\mathrm{CO}_{2}$. Science (Washington, DC) 298:1987-1990.
Sherry, R.A., X. Zhou, S. Gu, J.A. Arnone, III, D.S. Schimel, P.S. Verburg, L.L. Wallace, and Y. Luo. 2007. Divergence of reproductive phenology under climate warming. Proc. Natl. Acad. Sci. USA 104:198-202.

Smith, S.D., T.E. Huxman, S.F. Zitzer, T.N. Charlet, D.C. Housman, J.S. Coleman, L.K. Fenstermaker, J.R. Seemann, and R.S. Nowak. 2000. Elevated $\mathrm{CO}_{2}$ increases productivity and invasive species success in an arid ecosystem. Nature (London) 408:79-82.

Sonnemann, I., and V. Wolters. 2005. The microfood web of grassland soils respond to a moderate increase in atmospheric $\mathrm{CO}_{2}$. Glob. Change Biol. 11:1148-1155.

Suter, D., J. Nösberger, and A. Lüscher. 2001. Response of perennial ryegrass to free-air $\mathrm{CO}_{2}$ enrichment (FACE) is related to the dynamics of sward structure during regrowth. Crop Sci. 41:810-817.

Svejcar, T.J., J. Bates, R.F. Angell, and R. Miller. 2003. The influence of precipitation timing on the sagebrush steppe ecosystem. p. 90-106. In J.F. Weltzin and G.R. McPherson (ed.) Changing precipitation regimes and terrestrial ecosystems. Univ. of Arizona Press, Tucson.

Thomson, A.M., R.A. Brown, N.J. Rosenberg, R.C. Izaurralde, and V.W. Benson. 2005. Climate change impacts for the conterminous USA: An integrated assessment Part 3. Dryland production of grain and forage crops. Clim. Change 69:43-65.

Thornley, J.H.M., and M.G.R. Cannell. 1997. Temperate grassland responses to climate change: An analysis using the Hurley Pasture Model. Ann. Bot. (London) 80:205-221.

Thornley, J.H.M., and M.G.R. Cannell. 2000. Dynamics of mineral $\mathrm{N}$ availability in grassland ecosystems under increased $\left[\mathrm{CO}_{2}\right]$ : Hypotheses evaluated using the Hurley Pasture model. Plant Soil 224:153-170.

Tubiello, F.N., J.F. Soussana, and S.M. Howden. 2007. Crop and pasture response to climate change.Proc. Natl.Acad.Sci. USA 104:19686-19690.

Ulyatt, M.J., P.R. Fennessy, P.V. Rattray, and K.R. Jagush. 1980. The nutritive value of supplements. p. 157-184. In K.R. Drew and P.F. Fennessy (ed.) Supplementary feeding. New Zealand Soc. of Animal Production, Mosgiel, NZ.

van Groenigen, K.-J., J. Six, B.A. Hungate, M.-A. Graaff, N. Van Breemen, and C. van Kessel. 2006. Element interactions limit soil carbon storage. Proc. Natl. Acad. Sci. USA 103:6571-6574.

Wan, S., D. Hui, L. Wallace, and Y. Luo. 2005. Direct and indirect effects of experimental warming on ecosystem carbon processes in a tallgrass prairie. Global Biogeochem. Cycles 19:2014 10.1029/2004GB002315.

Wang, G. 2005. Agricultural drought in a future climate: Results from 15 global climate models participating in the IPCC 4th assessment. Clim. Dyn. 25:739-753.

Weatherly, H.E., S.F. Zitzer, J.S. Coleman, and J.A. Arnone, III. 2003. In situ litter decomposition and litter quality in a Mojave Desert ecosystem: Effects of elevated atmospheric $\mathrm{CO}_{2}$ and interannual climate variability. Glob. Change Biol. 9:1223-1233.

Weltzin, J.F., and G.R. McPherson. 2003. Response of southwestern oak savannas to potential future precipitation regimes. p. 127-146. In J.F. Weltzin and G.R. McPherson (ed.) Changing precipitation regimes and terrestrial ecosystems. Univ. of Arizona Press, Tucson.

Williams, J.R., C.A. Jones, J.R. Kiniry, and D.A. Spanel. 1989. The EPIC crop growth-model. Trans. ASAE 32:497-511.

Wilsey, B.J. 1996. Urea additions and defoliation affect plant responses to elevated $\mathrm{CO}_{2}$ in a C3 grass from Yellowstone National Park. Oecologia 108:321-327.

Wilsey, B.J. 2001. Effects of elevated $\mathrm{CO}_{2}$ on the response of Phleum pratense and Poa pratensis to aboveground defoliation and root-feeding nematodes. Int. J. Plant Sci. 162:1275-1282.

Young, J.A. 1991. Cheatgrass. p. 408-418. In L.F. James et al. (ed.) Noxious range weeds. Westview, Boulder, CO.

Zavaleta, E.S., B.D. Thomas, N.R. Chiariello, G.P. Asner, M.R. Shaw, and C.B. Field. 2003. Plants reverse warming effect on ecosystem water balance. Proc. Natl. Acad. Sci. USA 100:9892-9893.

Ziska, L.H., J.B. Reeves, and B. Blank. 2005. The impact of recent increases in atmospheric $\mathrm{CO}_{2}$ on biomass production and vegetative retention of Cheatgrass (Bromus tectorum): Implications for fire disturbance. Glob. Change Biol. 11:1325-1332. 